Abstract P3-S7.16 Table 1 Association between Lactobacillus colonisation in the vagina and acquisition of bacterial vaginosis (BV)

\begin{tabular}{lllll}
\hline $\begin{array}{l}\text { Lactobacillus } \\
\text { spp. }\end{array}$ & $\begin{array}{l}\text { \# BV acquisitions } \\
\text { per woman-years }\end{array}$ & $\begin{array}{l}\text { Rate Per 100 } \\
\text { woman-years }\end{array}$ & $\begin{array}{l}\text { Unadjusted } \\
\text { HR (95\% CI) }\end{array}$ & p Value \\
\hline $\begin{array}{l}\text { L crispatus } \\
\text { Present }\end{array}$ & $14 / 35.5$ & 39 & $0.47(0.24$ to 0.90) & 0.023 \\
$\begin{array}{c}\text { Absent } \\
\text { jensenii }\end{array}$ & $26 / 29.8$ & 87 & & \\
$\begin{array}{c}\text { Present } \\
\text { Absent }\end{array}$ & $18 / 22.6$ & 80 & $1.42(0.76$ to 2.66) & 0.270 \\
$\begin{array}{c}\text { L gasseri } \\
\text { Present }\end{array}$ & $11 / 16.1$ & 52 & & \\
Absent & $29 / 49.3$ & 68 & $1.08(0.54$ to 2.17) & 0.820 \\
$\begin{array}{c}\text { iners } \\
\text { Present }\end{array}$ & $13 / 20.2$ & 59 & & \\
Absent & $27 / 45.1$ & 64 & $1.13(0.60$ to 2.13) & 0.695 \\
\hline
\end{tabular}

\section{P3-S7.17 NONINVASIVE HIGH RESOLUTION IMAGING WITH OPTICAL COHERENCE TOMOGRAPHY FOR VAGINAL PRODUCT SAFETY ASSESSMENT IN WOMEN}

doi:10.1136/sextrans-2011-050108.500

${ }^{1} \mathrm{~K}$ Vincent, ${ }^{2} \mathrm{~L}$ Stanberry, ${ }^{3} \mathrm{~T}$ Moench, ${ }^{4} \mathrm{C}$ R Breitkopf, ${ }^{1} \mathrm{M}$ Loza, ${ }^{1} \mathrm{~J}$ Wei, ${ }^{5} \mathrm{~J}$ Paull, ${ }^{6} \mathrm{~J}$ Grady, ${ }^{1} \mathrm{M}$ Motamedi, ${ }^{2} \mathrm{~S}$ Rosenthal. ${ }^{1}$ University of Texas Medical Branch, Galveston, USA; ${ }^{2}$ Columbia University, USA; ${ }^{3}$ ReProtect, USA; ${ }^{4}$ Mayo Clinic, USA; ${ }^{5}$ Starpharma, Australia; ${ }^{6}$ University of Connecticut Health Center, USA

Background Prevention of HIV and other STDs using vaginal microbicides must be safe. Colposcopy has not been shown to predict microbicide safety; therefore a more sensitive method is needed in safety evaluations of these vaginal products. The use of optical coherence tomography (OCT) has shown increased sensitivity to tissue injury over colposcopy in animal models. We describe a randomised double blind clinical trial using OCT to detect epithelial changes and injury related to vaginal microbicide use.

Methods 30 women aged $18-45$ were randomised to use hydroxyethyl cellulose (HEC) placebo or nonoxynol-9 (N-9) vaginal gel twice daily for 5.5 days. Imaging with colposcopy and OCT was performed prior to product use, within $6 \mathrm{~h}$ of last dose of product, and 1 week after discontinuation of product. Colposcopy was graded based on vascular and epithelial disruption and erythema. OCT images were evaluated both by quantitative measurement of vaginal epithelial thickness and by use of a qualitative scoring system developed in the macaque to determine epithelial disruption and injury. Mixed model and significance of $p=0.05$ were used in data analysis.

Results Baseline colposcopy and OCT findings were similar between treatment groups. After treatment, there were no significant colposcopic differences in vascular or epithelial disruption between treatment groups, with only an increase in erythema noted after treatment in the $\mathrm{N}-9$ group $(\mathrm{p}=0.01)$. OCT detected differences between groups in OCT scores $(p<0.0001)$ and epithelial thickness, $(p=0.008)$, both indicators of epithelial injury, after treatment with N-9. One week after discontinuation of treatment, OCT scores were similar between treatment groups $(p=0.66)$ but epithelial thickness in the N-9 group was significantly thicker $(p=0.0003)$.

Conclusions OCT can be used in a clinical setting to detect epithelial injury and is more sensitive than colposcopy to detect microscopic epithelial disruption. In addition, it gives information about the thickness of the epithelium, a measure previously available only through invasive biopsy. Vaginal epithelium thinned after treatment in the N-9 group, but then thickened after discontinuation of N-9, possibly due to post injury epithelial proliferation. OCT should be considered for inclusion in clinical trials for the detection of productrelated toxicity to the vaginal and cervical epithelium.

\section{P3-S7.18 AETIOLOGICAL AGENTS OF INFECTIVE VAGINAL DISCHARGE AMONG WOMEN ATTENDING A STD CLINIC IN KUMASI, GHANA}

doi:10.1136/sextrans-2011-050108.501

T Agyarko-Poku. University of Science and Technology, Kumasi, Ghana

Objective To determine the prevalence of aetiological agents in Infective Vaginal Discharge among women attending a sexually transmitted infection (STI) clinic in Kumasi, Ghana. Methodology Three hundred (300) women consisting of 150 sex workers (SW) and 150 non-sex workers (NSW), attending the Suntreso STI clinic in Kumasi, with complaint of vaginal discharge were recruited for the study. Specimens for wet mount, $\mathrm{pH}$ determination, whiff test, Gram's stains, culture and polymerase chain reaction (PCR) were collected from the vagina and the cervix for microbial identification. The HIV status of the women was also determined by Western Blot Assay. Details regarding socio demographic characteristics of the women, symptoms and signs as well as sexual behaviour were recorded. Associations of these factors with each of the aetiological agent was recorded and adjusted for other risk factors.

Result Bacterial vaginosis was the most common cause of infective vaginal discharge (111/300: $37.0 \%, p=0.000$, SW-61/150\{40.7\% NSW $-58 / 150\{38.0 \%\}$ in the women, followed by Candida spp. (99/ 300: 32.7\%, $\mathrm{p}=0.000$, SW-41/150 $27.3 \%\}$; NSW-58/150\{38.0\%\}), Trichomonas vaginalis (20/300: $6.7 \%, \mathrm{p}=0.000) \quad \mathrm{SW}-12 / 150\{8.0 \%$; NSW-8/150\{5.3\%\}), Chlamydia trachomatis (9/300: 3.0\%, $\mathrm{p}=0.001$ SW-6/150\{4.0\%\}; NSW-3/150\{150\{2.0\%\}), Neisseria gonorrhoeae (6/300: $2.0 \%, p=0.014, \mathrm{SW}-4 / 150\{2.7 \%\} ; \mathrm{NSW}-2 / 150\{1.3 \%\})$ and Mycoplasma genitalium (10/300, 3.3\%, $\mathrm{p}=0.000, \mathrm{SW}-7 / 150\{2.0 \%\})$. $11.3 \%$ (34/300, 30 sex workers, four non-sex workers) of the women were HIV antibody positive. All of the aetiological agents except Chlamydia trachomatis $(\mathrm{p}=0.705)$ were associated with HIV infection. There was no difference in the types of aetiological agent found in sex workers (SW) and non-sex workers (NSW). Prevalence of all the aetiological agents was higher among sex workers except for Candida spp. (27.3\%, 41/150 compared with non-sex workers $(38.0 \%, 57 / 150)$. Younger age $(15-29$ years) was found to be the strongest predictor of infection.

Conclusion Agents of Bacteria vaginosis, Candida spp. and Trachomonas vaginalis continue to be the most predominant aetiological agents responsible for infective vaginal discharge among women in Kumasi, Ghana, while prevalence of Neisseria gonorrhoeae and Chlamydia trachomatis decline. Improving the detection and management of these organisms has significant public health implication for STI and possibly HIV control.

\section{P3-S7.19 DIVERSITY OF THE VAGINAL FLORA DETERMINED BY MOLECULAR METHODS IN HEALTHY WOMEN AND WOMEN WITH BACTERIAL VAGINOSIS IN THE BAY AREA, CALIFORNIA, USA}

doi:10.1136/sextrans-2011-050108.502

${ }^{1} \mathrm{E}$ Raphael, ${ }^{2} \mathrm{P}$ Madhivanan, ${ }^{1} \mathrm{~A}$ Reingold, ${ }^{3} \mathrm{~J}$ Klausner, ${ }^{1} \mathrm{~L}$ Riley, ${ }^{1} \mathrm{~S}$ Trammell. ${ }^{1}$ University of California, Berkeley, USA; ${ }^{2}$ Public Health Research Institute of India, Mysore, India; ${ }^{3}$ University of California, San Francisco, USA

Background The normal vaginal flora is primarily composed of Lactobacillus spp., which maintain the vaginal $\mathrm{pH}$ and create an inhospitable environment for other organisms. Bacterial vaginosis 